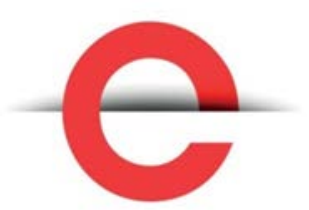

U T S

e PRE S S
Cosmopolitan

Civil Societies: an

Interdisciplinary

Journal

Vol. 9, No. 3

2017

(C) 2017 Kyungja Jung, Bronwen Dalton and Jacqueline Willis. This is an Open Access article distributed under the terms of the Creative Commons Attribution 4.0 Unported (CC BY 4.0) License (https:// creativecommons.org/ licenses/by/4.0/), allowing third parties to copy and redistribute the material in any medium or format and to remix, transform, and build upon the material for any purpose, even commercially, provided the original work is properly cited and states its license.

Citation: Jung, K., Dalton, B. \& Willis, J. 2017. The Onward Migration of North Korean Refugees to Australia: In Search of Cosmopolitan Habitus. Cosmopolitan Civil Societies: an Interdisciplinary Journal. 9(3),1-20.

http://dx.doi.org/10.5130/ccs.v9 $\underline{i 3.5506}$

ISSN 1837-5391 | Published by UTS EPRESS | mcs.epress.lib.uts.edu.au
REFEREED PAPER

\section{The Onward Migration of North Korean Refugees to Australia: In Search of Cosmopolitan Habitus}

\section{Kyungja Jung}

University of Technology Sydney, Australia

\section{Bronwen Dalton}

University of Technology Sydney, Australia

\section{Jacqueline Willis}

University of Technology Sydney, Australia

Corresponding author: Kyungja Jung, Social and Political Sciences, Faculty of Arts and Social Sciences, University of Technology Sydney, 15 Broadway, Ultimo, NSW 2007, Australia. Kyungja.Jung@uts.edu.au

DOI: http://dx.doi.org/10.5130/ccs.v9i3.5506

\begin{abstract}
Based on assumed common ethnicity, language and culture, and generous settlement programs, South Korea is believed to be the best country for North Korean defectors to restart their lives. This is, however, not necessarily the case. Since the mid-2000s, 2000 to 3000 North Koreans have allegedly settled in the UK, Canada, the US, Australia and EU countries. Despite this trend and its broader implications, the onward migration process of North Korean refugees, together with their motivations and lived experiences, remain poorly addressed in academic research. Drawing from the unique experience of North Korean refugees' onward movement to Australia, the paper suggests that discarding a North Korean identity and habitus and gaining cosmopolitan habitus are the main reasons behind North Korean defectors' onward migration. The paper is the first empirical study on North Korean refugees resettled in Australia to adopt habitus as a theoretical framework, and thus provides new insight into migration studies..
\end{abstract}

\section{Keywords}

North Korea; North Korean refugees in Australia; onward migration; refugee policy and settlement policy; habitus; cosmopolitanism 


\section{Introduction}

North Koreans are on the move after they have fled their country. First, they head for China. Estimates of the number of North Koreans in China are broad, ranging from 60,000 to 300,000. In particular, since famine struck North Korea in the mid-1990s, hundreds of thousands of North Koreans, dubbed 'exodus' of North Koreans (Lankov 2006, p. 110), have crossed the Tumen River into northeast China. Problematically, concerned about the destabilising effects that the crossing of a large number of North Korean refugees into China might have on North Korea (Cohen 2012), China does not recognise North Korean defectors ${ }^{1}$ as refugees, but illegal economic migrants. China also has bilateral treaties with North Korea, such as those of the early 1960s and 1986, which require the return of all illegal North Korean migrants in China to North Korea (Charny 2004, p. 81). Since the mid-1990s, China has allegedly repatriated tens of thousands of North Koreans. Due to this situation in China, a significant proportion of North Koreans have resettled in South Korea or another country.

North Koreans' situation in South Korea is far different from refugees settling in other countries. As the South Korean government considers itself to be the sole legitimate authority on the Korean peninsula, North Korean defectors are seen as South Korean citizens, not refugees (Lankov 2006). Some 27,810 North Koreans have settled in South Korea between the end of the 1950-53 Korean War and early 2015, with numbers increasing markedly following the mid-1990s famine period (Ministry of Unification, 2015). To deal with this sharp increase, the South Korean government enacted the North Korean Refugees Protection and Settlement Support Act 1997. Under the Act, a series of support programs aimed at North Korean refugees only, ranging from protection, education, employment, accommodation, medical care and support for minimum living standards, have been implemented (Ministry of Unification 2015).

Despite assumed common ethnicity, language and culture and generous settlement programs, some North Korean refugees in South Korea have attempted onward migration by seeking refugee status in the US, Canada, Australia, Europe and other countries, particularly since the implementation of the US North Korean Human Rights Act (NKHRA) in 2004. According to the United Nations High Commissioner for Refugees (UNHCR 2016a), the number of North Korean refugees around the world in 2015 (not including South Korea and China) amounted to 1,089, with most going to the United Kingdom (608), Canada (126), Germany (101), Russia (72), the Netherlands (56), Belgium (46), Australia (26) and the United States (19). Some North Korean defectors made refugee claims to more than one country (Kim 2013). This has prompted concern on the part of the South Korean government as to the effectiveness of its resettlement programs. Internationally, countries such as Australia, Canada and the US are grappling with how to deal with serial refugee claims by North Korean defectors who have already been granted citizenship in South Korea.

\footnotetext{
${ }^{1}$ The North Korean defectors referred to are asylum seekers in Australia, but in South Korea, they have already been granted refugee status. In this paper, we thus use the three terms: defectors, refugees and asylum seekers interchangeably.
} 
Theoretically, the onward migration of North Korean refugees challenges findings that suggest that onward moves are largely motivated by economic concerns. Most research understands onward migration to be motivated by the pursuit of improved economic conditions and wellbeing, or an effort to overcome a range of difficulties, including discrimination and racism in a first settled county (Ahrens et al. 2016). Yet, very little attention has been paid to non-economic factors, such as the habitus of migrants (or for North Korean refugees, the acquisition of cosmopolitan habitus), as a potential driving force behind the onward move. Although we cannot deny that there are structural and economic reasons behind onward migration, attention needs to be paid to how structural inequality has played out in the embodiment of resettled migrants and how this might affect onward migration decisions. Using Bourdieu's concept of habitus as a theoretical framework, this paper thus addresses the motivations and experiences of North Korean refugees' participation in onward migration processes. Data are drawn from interviews with North Korean defectors living in Australia and legal cases involving North Korean defectors.

\section{Interviews with North Koreans resettled/living in Australia}

Due to their invisibility in Australian immigration statistics, the number of North Korean refugees or asylum seekers in Australia is uncertain. Data from the UNHCR (2016b) ${ }^{2}$ indicate that 159 North Koreans applied for refugee settlement visas to Australia between 2000 and 2015 - thirty-three successfully - making Australia one of the key destinations for

Figure 1: North Koreans Seeking Asylum in Australia (2000-15)

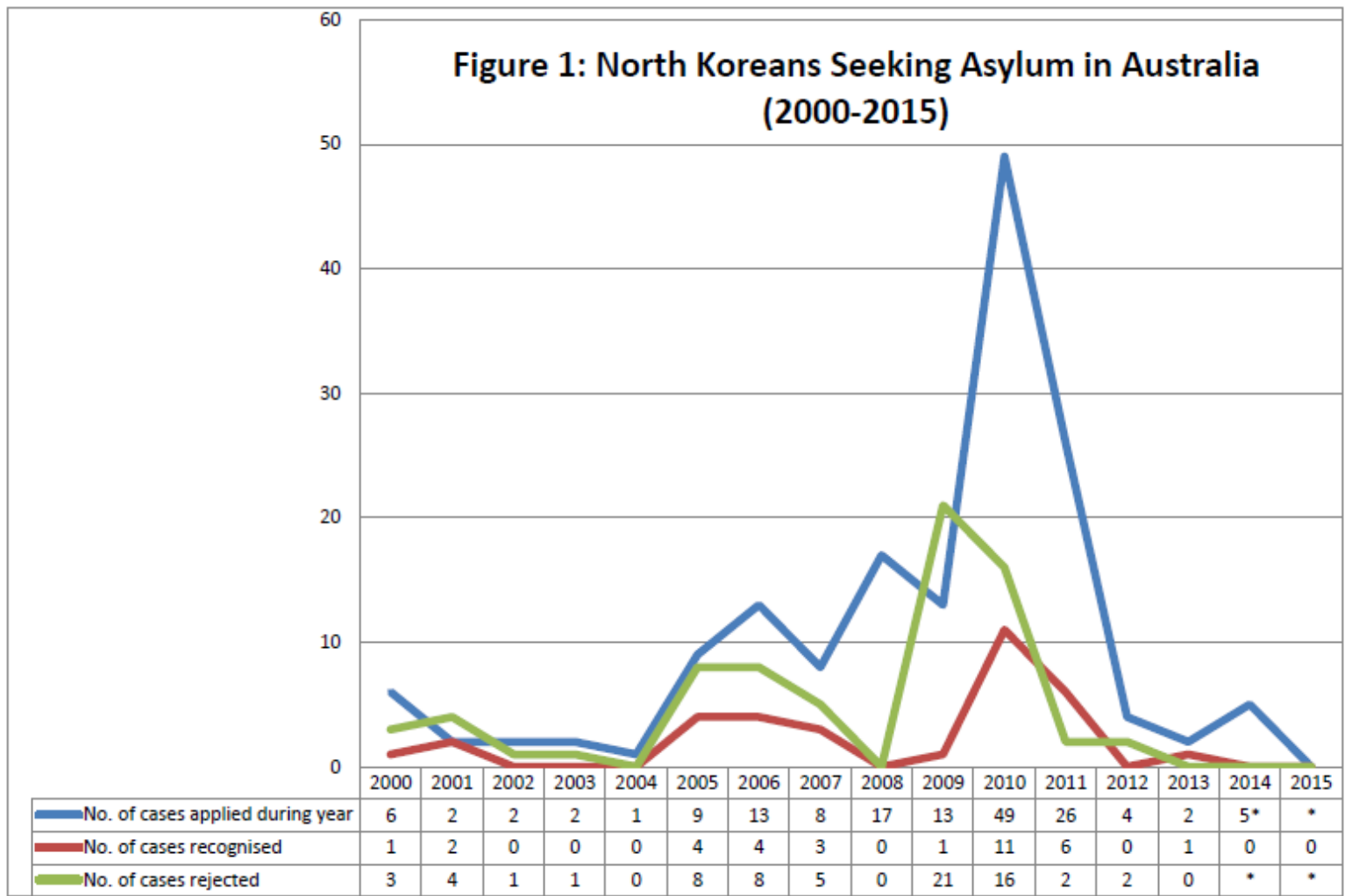

\footnotetext{
${ }^{2}$ Some figures from 2014 and 2015 have been redacted to protect applicants' anonymity. Cells marked by an asterisk and figures with an asterisk indicate redacted figures (UNHCR 2016b).
} 
North Korean asylum seekers. According to the interviewees for this study, between sixty and seventy North Koreans were living in Sydney in 2011, decreasing to around forty following a hardening of the Department of Immigration and Citizenship’s (DIAC) position on illegal North Korean asylum seekers in early 2012. This is in line with UNHCR data in Figure 1. However, one Australian media report indicates that in 2012 alone, seventy North Korean asylum seekers were staying in Australia illegally after failing to obtain a refugee protection visa. Some face deportation to South Korea (Stewart 2012).

This study is based on a small, convenience and snowball sample: all participants were based in Sydney at the time of interviews and consented to be interviewed. Given the small number of North Korean refugees living in Australia and their undefined legal status, it was hard to recruit research participants. We contacted organisations such as Korean community churches, migration agents and asylum seekers centres that were understood to have frequent contact with North Korean refugees in Australia and asked them to help with the recruitment of potential participants. With the help of these groups and snowballing techniques, we conducted semi-structured interviews with seven females and seven males staying in Australia from April 2012 to January 2013 and in April 2014. Interviews took place at times and in locations convenient to participants, lasted two to three hours and were recorded with participants' consent. Interview questions included the motivations behind their decision to leave South Korea, why Australia was chosen, and the experiences of living in Australia (education, housing, social services and other social activities).

Our interviewees are highly educated and comparatively young. Ten of the fourteen interviewees are college graduates or currently studying at university. Four are in their twenties, four in their thirties, two in their forties and four in their fifties. Identifying details have been omitted to protect participants' privacy. To complement the small number of research participants, we have also analysed forty-one Refugee Review Tribunal (RRTA) cases, one Federal Magistrate case and two Federal Court (FCA) cases involving North Korean defectors from 1996 to 2014. This has been combined with interviews with four support workers, media reports, participant and non-participant observation at North Korean refugee events, and a detention centre visit.

\section{Onward migration and cosmopolitan habitus}

Onward migration, such as the secondary movement of refugees and asylum seekers, is often perceived as a problem to manage rather than a process to study and understand. Unlike earlier refugees and migrants who moved to one country and established themselves there permanently, nowadays refugees and migrants often feel compelled to move to another country, so that they can operate between opportunities and constraints. Yet research on this area is very rudimentary and suggests that the reasons behind onward movements are various, but contradictory. Research has found that the main push factors to drive onward moves are a range of difficulties faced in a first settlement country. A study with naturalised EU citizens suggests that onward migration is largely due to the discrimination and racism experienced in the previous country of residence (Ahrens et al. 2016). Similarly, Van Liempt's (2011) study on the emigration of Dutch-Somalis to Leicester and London in the UK shows 
disappointment with the Netherlands as the reason for the onward move. A study on twelve Somalis who left Denmark for the UK after first gaining citizenship as refugees, found that onward migration decisions were largely based upon dissatisfaction with life in Denmark (Bang Nielsen 2004). The research on Iranian onward migrants in Sweden shows that 'the majority have faced difficulties in securing meaningful employment', and that limited employment and income may have prompted their decision to move (Kelly 2011, p. 21). However, the existing research does not offer further detail on why, and on which grounds, the refugees and migrants experienced difficulties and discrimination. For example, research in the US has found that migrants who speak English well, have graduate-level education and high-income levels, still made multiple international moves (Takenaka 2007). This research implies that the researchers need to go beyond the economic motivations thesis in dealing with onward migration.

Some researchers highlight, in the highly globalised world, the significance of mobility itself in migrants' lives and regard onward migration as being a way for people to exercise their limited capacity for agency by moving on to places that better meet their social, economic and cultural needs (Kelly 2013; Skeggs 2004). Mobility itself is a resource that is not equally available to everyone, but is facilitated by unique personal histories, diasporic consciousness, diasporic networks and high levels of education and skill. Attention needs to be paid to the non-economic factors driving refugees to undertake onward migration. Therefore, Bourdieu's (1984; 1990) concept of habitus provides a new perspective on migration studies.

Habitus is a collection of culturally and historically specific knowledge, values and dispositions. Through habitus, one internalises the legitimacy of one's inclusion or exclusion in a given society. Habitus is a structuring principle that shapes our everyday practices, but is mediated and reproduced only through individual bodily experience. One's habitus affects the body in the form of clothing, grooming, in the ways of walking, talking, standing, looking, sitting, interacting and so on. In this way, habitus is the product of history and accumulation of knowledge and experience of members of a given society who have a common social positioning (Lechte 2003, pp. 103-104). Habitus also includes taste as Bourdieu (1984, p. 190) explains that 'the body is the most indisputable materialisation of class taste'. That is, the body and its presentation are the manifestation of the tastes, values and cultural capital of a class or group. Cultural capital appears in lifestyles and habitus and is reproduced through being a member of a given class/group or in a given material circumstance.

Not only are social class and material possessions critical for migrants to adjust to a new country, but so too is embodied habitus. When migrants/refugees move to another country that is radically different from the one that shaped their primary habitus, they feel out of place and displaced. In the crisis of a sudden change in place or space, migrants' habitus becomes dysfunctional as they are unable to perform as expected. Their refugee and migrant status (mostly low social and economic status) as well as different habitus (accent, taste and embodiment) serve as a source of discrimination and isolation. 
Bourdieu (1990) emphasises the potential for habitus to be reconstructed or changed in the event of encounters with the unfamiliar, such as resettling in a new country. He defines habitus as 'a complex interplay between past and present' (Reay et al. 2009, p. 1104) and notes that rather than being fixed, habitus is learned, acquired and transformed, both through new experiences in one's social environment and the process of socialisation. As Reay et al. (2009, p. 1104) explain, although an individual's past experiences and history play a fundamental role in shaping their habitus, habitus is simultaneously 'permeable and responsive' to new experiences and encounters. Exploring this reconstituting potential, Reay et al. (2009) consider the experiences of working-class students undertaking education at an élite institution. They find that the schooling is 'particularly effective' in resocialising the students and reshaping their habitus (Reay et al. 2009, p. 1105). In a similar vein, we pursue this line of enquiry using the example of North Korean defectors, exploring the extent to which they are able to reinvent their old habitus when encountering new social fields through onward migration.

North Koreans who have settled in South Korea wish to rid themselves of their North Korean habitus and learn South Korean habitus. Resettled North Koreans have also become aware that to be like South Koreans, they need to acquire cosmopolitan habitus which includes experience of living overseas, foreign language competency (in particular, English), and studying/living abroad. In the era of globalisation, such competencies are a necessary requirement of being a member of the global community, and one cannot truly fit in, or be competitive, without such skills. According to Weenink (2008), cosmopolitan habitus encompasses both physical and mental proclivities and proficiencies that equip individuals to be successful global citizens. While living and engaging in cosmopolitan/transnational spaces, individuals learn to embody cultural tastes and discourses, giving them 'a competitive edge’ (Weenink 2008, p. 1092). North Koreans, in general do not possess cultural capital to give them cosmopolitan habitus. Moving again to another country might be the only option to construct cosmopolitan habitus for themselves and their children.

Cosmopolitan habitus specifically relates to both a 'global' skill and mindset, which individuals can draw on to successfully negotiate global communities. This entails cultural tastes and knowledge that increase global competitiveness and participation (Weenink 2008, p. 1092). Attaining English language competency, for example, constitutes a skill that would serve to bolster one's cultural and cosmopolitan capital, increasing the chance of upward social mobility and success in the global arena (Bourdieu 1986; Weenink 2008). This also involves demonstrating a sensitivity and acceptance of difference and diversity, both in mind and practice (Beck \& Sznaider 2006). Cosmopolitan habitus also tends to foster a global outlook whereby individuals work to understand their realities and experiences from a global, rather than local, perspective. This engenders mental and physical flexibility that encourages fluid/ hybrid identities and promotes a sense of not being tied to any geographical or ethnic location (Giddens 1991; Hayden et al. 2000). 


\section{North Korean habitus in South Korea}

Perceptible differences in their use of language, differences in fashion, comportment and other social behaviours set North Koreans apart from 'the cosmopolitan, image-conscious socialites' of the South (Bell 2014, p. 103). Upon arrival in South Korea, North Korean refugees undergo three months of 'training', offered by the South Korean Government, during which time they learn about the South Korean political and economic system, and other practical skills, such as driving and 'correcting' their North Korean accent (Choo 2006, p. 583). Nonetheless, for the majority of North Korean refugees, life in South Korea constitutes 'the polar opposite' of life in the North (Bell 2014, p. 102).

North Korean refugees must also deal with being the subjects of negative stereotypes which depict them as 'cold-blooded communists ... unfeminine women workers, and ... starving and helpless refugees' (Choo 2006, p. 590). The abovementioned differences in language, dress and manner serve to perpetuate these stereotypes and separate North Korean refugees from mainstream South Korean society. They also present obstacles to successful integration and resettlement as North Koreans are constantly presented as 'other', reinforcing a national discourse that has distinguished North Koreans from South Koreans since the division of the peninsula (Choo 2006, p. 590). In seeking to remove such noticeable distinctions, North Korean refugees attempt to shed their accents (Choo 2006; Bell 2014), obtain cosmetic surgery and adopt South Korean styles of living and self-presentation (taste and make up), including the conspicuous consumption of high-end brand items (Bell 2014). As a male participant in his early forties recalled: 'We were working really hard to earn money sufficient enough to buy a good car. We bought the most expensive car in our neighbourhood so that we were not looked down upon as North Koreans by our South Korean neighbours'. In acknowledgement of the stigmatising potential of the North Korean accent, the South Korean government provides South Korean accent lessons as part of its three month education package offered to North Korean refugees (Choo 2006, p. 591). Refugee testimony even indicates that some go to a special accent correcting institute to obtain the 'perfect Seoulite accent', mastered by holding a pen between their lips (cited in Choo 2006, p. 590).

Despite such efforts, this conspicuous and noticeable North Korean habitus results in a level of mistreatment, discrimination, alienation and suspicion that presents a genuine obstacle to resettlement (Sung \& Go 2014). Testifying to these difficulties, a report found that 45.6 percent of South Koreans surveyed held prejudice and stereotypes about North Korean refugees based on their distinct embodiment and accent (NHRC 2014). Another Korean Educational Development Institute (KEDI [2011]) survey found that 10.7 percent of a total 429 elementary and middle school North Korean refugee students admitted to being subject to either discrimination or ostracism on account of being North Korean. In another study based in the workplace, North Korean refugees reported receiving similar reactions from their co-workers and superiors. This prejudice and stereotyping has limited their opportunities, including employment, making it virtually impossible for North Korean defectors to move up the social ladder into the middle or upper-middle classes. A survey of 1,785 refugees living in South Korea showed that in 2014 only 53.1 percent were employed and that 19.8 percent 
were employed as casuals (Korea Hana Foundation 2014). Both of these statistics indicated a worse situation for North Koreans than the country as a whole, with South Korea's total employment rate sitting at 60.8 percent, and its casual employee rate at 6.1 percent.

Employed defectors also work more than the average South Korean work week of 44.1 hours, clocking in forty-seven hours per week. They are also not as generously renumerated as their South Korean counterparts, earning on average KRW1.47 million per month, compared to the national average of KRW2.23 million (US\$1=KRW1,100). Many North Korean refugees feel alienated and isolated in South Korean society, finding it difficult to build relationships, or associate with, their South Korean peers (Kim \& Lee 2013).

To survive in South Korea, North Korean refugees often hide their identity while trying to learn South Korean habitus. When asked, 58.4 percent of young defectors voiced a reluctance to admit their North Korean origins (Korea Hana Foundation 2014). Similarly, fifty-four percent of surveyed primary and middle school North Korean refugee students disclosed that they would hide that they were North Korean if given the opportunity to transfer to a different school (KEDI 2011). All interviewees for this study indicated their desire not to be noticed as North Korean and to raise their children without the stigma of being North Korean, which could not be escaped while living in South Korea. Two interviewees working as welders in Australia mentioned that in order to avoid discrimination in South Korea and secure employment, they had to pretend that they were from the South Korean border province of Gangwondo, northeast of Seoul, where the accent and dialect are similar to those of North Korea:

We rang the agencies and they asked us if we were Chinese Koreans. We said, 'no' then they told us 'come to the office'.... They interviewed us and found that we had a North Korean accent. They told us that they would give us a call. That's the end of the story.

In addition to facing discrimination from their South Korean peers, their easily noticeable 'North Koreanness' also exposes them to North Korean spies, threatening their safety and that of their families in North Korea, as well as their psychological wellbeing. One female interviewee in her thirties said:

I am always worried about the family I left behind in North Korea. North Korea is very close to the South. Information about us could be easily collected by North Korean spies. That might cause my family to be punished and suffer retaliation. I want to live far away from North Korea.

These same concerns are reflected in many of the Refugee Review Tribunal cases analysed (see RRTA 2004; RRTA 2005; RRTA 2007, for example). North Korean refugees wish to move far away from the Koreas with the hope to not be seen as North Korean, to shed North Korean habitus, and to reconstruct a new identity in a new country.

North Korean habitus, deeply embedded in their body and identity through accent, taste and social interactions, is a major push factor driving North Korean defectors' decisions to leave for another country. North Koreans want to rid themselves of their distinctive cultural 
characteristics and transition to modern/cosmopolitan individuals. More than sixty years of separation and division have led these two groups to live in totally different social spaces and espouse divergent political ideologies. Gaining legal citizenship does not necessarily make North Koreans become like South Koreans. North Korean habitus serves as a distinct marker of difference and a major obstacle to North Koreans remaking themselves as South Korean citizens.

\section{In pursuit of Cosmopolitan Habitus: global aspiration and 'English fever' in South}

\section{Korea}

In the era of globalisation, South Korea is enveloped by an 'English fever' whereby English education is highly valued as a symbol of prestige and high social standing (Lee 2014, p. 21). For Koreans, learning a foreign language, such as English, constitutes a type of 'cosmopolitan knowledge', providing influence potential in the form of social and cultural (cosmopolitan) capital (Weenink 2008, p. 1092). As a much sought after symbol of class distinction, English has become crucial to upward social mobility and competitiveness in the global market (Rizvi 2005; Waters 2008; Kenway \& Fahey 2014).

Working to ensure its international competitiveness, South Korea invests heavily in education. In 2012, nearly twelve percent of all consumer spending was devoted to education, and principally to English language tuition (ICEF Monitor 2014). In the mid-1990s, middle and upper-class South Korean parents began to send their children to primarily Englishspeaking countries in rapidly expanding numbers (Lee \& Koo 2006). Some families have even decided to emigrate to teach their children English from an early age. This trend has been dubbed gyoyukimin (educational immigration), so pervasive that the term entered the Korean language as a neologism in 1997, defined as 'immigrating to a foreign country in order for children to be educated in a better environment' (Lee 2014, p. 28).

Another phenomenon arising from English zeal in South Korea is gireogi gajok (wild goose family) middle-class transnational families. Children, accompanied by their mother, study overseas in English speaking countries, while the father supports the endeavour financially from Korea (Shin 2014, p. 100). The fathers of such families are dubbed gireogi (wild geese), as these animals fly long distances, often across oceans, to form their families (Lee \& Koo 2006). A survey conducted by South Korean newspaper Dong-A Ilbo found that a quarter of all South Koreans strongly aspired to partake in 'educational immigration', while 21.8 percent had desires for their children to study abroad. Similarly, twelve percent of all respondents indicated a willingness to be a gireogi family (Lee 2014, pp. 28-29). These findings were echoed in another survey of 1008 South Koreans, which shows that 44.7 percent of respondents would send their children overseas for the purposes of education if financially capable of doing so (Bae 2007, cited in Lee 2014, p. 29). It is no exaggeration to say that 'the whole nation has an inferiority complex about English' (Choi 2005, cited in Lee 2014, p. 45). There is certainly an 'English Divide' and social division created by differing levels of access to English language tuition (Shin 2014, p. 100 - emphasis in original). 
Under the North Korean Songbun caste system, foreign language learning is only available to those privileged enough to find themselves at the top of the social hierarchy. Though, the motivation to study English is relatively limited given the lack of real-life application potential imposed by the government's restrictions on overseas travel. Those unlikely to gain permission to travel from the government place little clout on learning other languages and are not overly inclined to make the effort required to gain foreign language skills (The Guardian, 5 February 2015). Without the required cultural capital to compete, rigid social stratification and fierce competition in South Korea exacerbate the divisions between South Koreans and North Korean refugees. English competency has thus become one of the most challenging issues, especially for young North Korean defectors in South Korea. More than a quarter of North Korean defectors who entered universities in Seoul and Gyeonggi Province through the special admission process, dropped out due to the language barrier (Chosunilbo, 5 October 2010). The realisation that they could not compete with South Korean-born peers and had no job prospects has been a motivating factor for the onward move of many North Korean defectors (Oh 2011).

Two empirical studies on the onward migration of North Korean refugees suggest that the desire to acquire cosmopolitan habitus has influenced defectors' decisions to seek asylum in English-speaking countries, such as the US and UK. A study based on eleven North Korean refugees found that they left South Korea for the US because of discrimination and hardship, and in the hope of better opportunities, education, and in particular, learning English (see Shin 2008). Another study of thirteen North Koreans who had left South Korea for the UK also found English education was one of the main motives for their onward migration, along with poverty, insecurity, discrimination, prejudice and a lack of social network (Oh 2011). Therefore, some defectors have sought asylum in English-speaking countries like Australia to increase their competitiveness, employment prospects and ensure a better future for themselves and their children by acquiring cosmopolitan habitus through learning English and cross-cultural experience.

All interviewees for our research highlighted access to immersive English education as the main reason for their move to Australia. North Korean refugees who are unlikely to have the social, cultural or financial capital to study abroad and send their children overseas, take this onward migration opportunity seriously. Many North Koreans use a refugee application as a way of learning English free of charge, or providing that opportunity to their children. One male interviewee in his forties remarked:

I decided to come to Australia for my children's education. South Koreans send their children overseas to study English, but I can't afford that. I thought even if my application for asylum was unsuccessful, my family would have stayed in Australia and my kids could have experienced Australian life, such as learning English, at least for the period the application was being processed.

In this way, the decision to move to Australia though applying for another refugee protection visa is seen as a strategy of transnational education migration for them and their children to become cosmopolitan citizens in the era of globalisation. Another female participant in her thirties emphasised this point clearly when she said: 'I want to raise my kids as world-class 
citizens. Unlike me, I want to give them the chance to learn English and experience many countries, so that one day they can be global elites regardless of their North Korean origins'.

North Koreans who have settled in South Korea wish to rid themselves of their North Korean habitus and be like South Koreans. Resettled North Koreans have also become aware that to be like South Koreans, they need to acquire cosmopolitan habitus which includes experience of living overseas, foreign language competency (in particular, English), and studying/living abroad. As most North Korean refugees have limited economic, social and cultural capital, repeated refugee claims might be their only option to construct cosmopolitan habitus for themselves and their children.

\section{Challenges to acquiring cosmopolitan habitus}

The question remains whether onward migration to Australia has fulfilled the desires of North Korean refugees and provided them with opportunities not available in South Korea. Despite desires and efforts to reinvent themselves through onward migration, most North Korean asylum seekers in Sydney are first hampered by undefined legal status.

Australia has pursued a hard line on granting asylum to North Koreans arriving from South Korea (Bell 2013) ${ }^{3}$. To be granted a protection visa, a North Korean applicant must meet the criteria specified in the 1958 Migration Act. A person must have a justifiable fear of persecution in their national country and, for whatever reason, not be able to seek protection from that country. North Korean defectors must also contend with the fact that Australian law considers North Koreans to be dual citizens of both North and South Korea. Thus, the common argument not to grant a protection visa to North Koreans is that since they also have South Korean nationality, they cannot be protected by Australia. As such, North Korean defectors are typically deported to South Korea within fourteen days (Stewart 2012). In 2011, eighty North Koreans found themselves in this situation, after the High Court of Australia ruled that protection could not be extended to refugees by Australia if they were already eligible for protection in a third country (Piotrowski 2013).

Stringent definitions of what constitutes persecution in Australian migration law present a further challenge to the onward migration of North Korean refugees to Australia. Our analysis of court cases reveals that a common argument not to grant a protection visa to North Korean defectors in Australia is that the difficulties they may experience in South Korea, including in finding employment 'do not amount to persecution' (RRTA 2007, para. 74). This same reasoning is applied to North Korean applicants’ claims of psychological harm.

The fact that some North Korean defectors employ unlawful methods also presents an obstacle to their seeking asylum in Australia. In this regard, brokers, often North Korean refugees who have resettled in other countries, play an important role, offering information

\footnotetext{
3 Some EU countries, as well as the UK and Canada, have also recently implemented increasingly rigorous screening procedures with respect to North Korean refugee claimants, so as to filter out fraudulent claims. As in the case of Australia, the UK government has rejected the applications of North Korean refugees with South Korean citizenship, requiring fingerprinting of refugees in order to check whether they lived in South Korea before coming to the UK (Choi 2011).
} 
and help with refugee applications, or even encouraging the use of unlawful methods. Research found that those with high levels of cosmopolitan capital acted as brokers providing those lacking such capital with the opportunity not only to gain knowledge and capital, but to exercise influence in their local communities (Weenink 2008). The three participants in this study who arrived in Australia directly from China recounted having received a broker's help. Among those interviewed, four said that they falsely claimed that they had come to Australia directly from China, concealing the fact they had been granted South Korean citizenship. Three of the remaining interviewees came to Australia directly from China, two via the UK and one via Canada, after having previously settled in South Korea.

Another concern is to assess if the applicant is a genuine North Korean refugee. In some claim cases analysed, such as Zhou v Minister for Immigration and Multicultural Affairs (MIMA) (FCA 2000), applicants were found to be ethnic Korean Chinese, not North Korean nationals. These ethnic Koreans from China study North Korean specifics, such as its history, songs, and politics. Some even present official documents such as birth certificates. Others offer North Korean bank notes, or Kim Il Sung badges as evidence of their supposed origins, though these are not considered valid evidence of nationality, as this kind of North Korean 'merchandise' can be purchased online (Choi 2011, para. 3). The fact that North Korean refugees often spend considerable lengths of time in China before migrating onward, further hampers discerning North Koreans from ethnic Chinese Koreans. For example, seven participants in this research had lived in China for more than three years after they fled North Korea and spoke Chinese fluently. This suspicion concerning the legitimacy of claims makes securing protection difficult.

One interviewee argues that not a single genuine North Korean refugee has been granted a refugee protection visa in Australia, and that all of those who had received visas were ethnic Koreans from China. However, analysis of forty-one Refugee Review Tribunal cases between 1996 and 2014 suggests two instances of genuine North Korean refugees being granted protection visas. The first successful case analysed was in 1996. The applicant was born in North Korea, though later escaped and became a South Korean citizen. He made the onward move to Australia in 1984, where he discovered he had living relatives still in North Korea. He initiated contact with them via telephone with the assistance of relatives in China, maintaining communication for approximately nine years. Despite already holding South Korean citizenship, he was granted protection on account of South Korea's strict National Security Law, which prohibits unauthorised contact with North Korea, including relatives. Noting that the South Korean government is 'highly sensitive about contacts between the North and South' and deeming there to be 'a real chance' of 'treatment amounting to persecution,' including interrogation or imprisonment if the man returned to South Korea, he and his wife were granted protection visas (RRTA 1996, para. 83).

The second successful case analysed was in 2000. The applicant arrived in Australia unlawfully from China, with no identification. He claimed to have defected as a youth by crossing the Amnok River into China after the death of his father as a political prisoner caused him to suffer much ill-treatment. He lived in China as a farmer for many years, though a crackdown on North Korean refugees and the fear of repatriation saw him leave China for 
Australia. The determination that he 'face[d] a real chance of being returned to North Korea' in China, and punished by North Korean authorities saw the applicant granted a protection visa (RRTA 2000, para. 43).

Yet these cases are not the norm and both were ruled on prior to the DIAC crack down on North Korean refugees in 2012. The majority of cases are denied. Highlighting the difficulties inherent in the process, by April 2014, five of the fourteen people interviewed for this study had already left Australia for South Korea after their refugee applications were rejected. This uncertain legal status exacerbates North Korean asylum seekers' hardships in Australia. While their refugee protection visa applications are being processed, they are eligible to apply for financial support, health care and legal services. However, once their applications are declined they can no longer access these services. Interviewees lived in fear of deportation, and did not qualify for social welfare services such as health care and free education. One male participant working as a cleaner said he could not visit a doctor when he got sick because of his unsettled legal status. A couple with two children aged two and four years old were concerned about their children's education as they could not send them to childcare or kindergarten. Another participant who worked as a house painter said that he only had a few coins in his wallet and could not afford to buy milk and nappies for his two small children, let alone take them to a hospital for vaccinations.

\section{Realities of living as a cosmopolitan: the precariousness of life in Australia}

Interviewees mostly supported themselves and their families by doing labour-intensive, mostly casual, precarious and cash-in-hand work, working fifty to seventy hours per week. Due to these often physically intensive and long hours of work, North Koreans in Australia hardly found time for leisure or other social and cultural activities, let alone learning English. In response to the question of whether he enjoyed living in Australia, one male interviewee said:

There is nothing I am satisfied with here in Australia. I get up at five in the morning and come back from work after six in the evening. Then, I take a shower, have dinner, watch a Korean drama, and go to sleep again. This is my daily routine. There is no space in my mind where I could think about whether I am happy or unhappy.

Another male participant, a graduate of North Korea’s premier university, Kim Il Sung University, revealed that his life as a nogada (blue-collar worker) in Australia was even worse than his life in North or South Korea, saying:

I made a living by giving public lectures in South Korea, mostly in Seoul. I used to give one or two lectures every day which paid me between AUD 180 to AUD 700 per lecture. In South Korea, I owned a house [the South Korean government provides housing as part of a settlement package] and I never did any physically intensive work - not even in North Korea. I was a company executive in North Korea and had my own chauffeur. 
In spite of access to casual jobs, the precariousness of their jobs and high living expenses meant that interviewees' living arrangements were basic. Renting an entire apartment was well beyond their means. Two of the homes visited during the interview process revealed how poor living conditions were. One house was run-down, contained little furniture, and was run as a boarding house by a female refugee. Another tiny unit did not even have beds. Highlighting the financially precarious situation of North Korean refugees in Australia, a male participant who worked as a cleaner in a big supermarket said that he had sent hardly any money to his family in South Korea recently.

Ironically, language incompetency presents a major obstacle to adjustment in Australia. North Korean refugees' lack of English competency constrains their employment opportunities and social interactions. Those interviewed mostly socialised with other North Koreans, Chinese Koreans and Korean Australians and were socially isolated from so-called mainstream Australian society. One fifty-year-old male refugee said: 'Although we live in Australia geographically, we still live in South Korea'. Those who attend an English language school are juggling work with study to financially support themselves and their family members. The majority of interviewees were working in informal sectors such as cleaning, painting, shop-keeping, child-minding, waitressing and tiling, mostly in AustralianKorean-owned small businesses, which do not require legal documents or English language skills. Their language competency and unfamiliarity in Australia have led most to live in areas where there are large Korean communities, and near railway stations where many Korean businesses and shops are located. Eleven of the fourteen participants shared a unit with other people, usually other North Korean refugees and Chinese Koreans, or lived in a boarding house, often run by a North Korean refugee. The North Korean asylum seekers are thus consigned to marginality in the Australian labour market and society due to not yet attained legal status and cosmopolitan habitus (in particular, language competency).

\section{Cosmopolitanism, Transnationality and 'Asian' identity: 'I wish to live here no matter}

\section{what'}

Despite these challenges and lower quality of life (poor housing, precarious employment and social isolation), all those interviewed wished to stay and live in Australia if possible. During their stay in Australia, although brief, they seemed to develop 'a cosmopolitan sensibility and a willingness to be, or the experience of being, transnationally mobile' (Maxwell \& Aggleton 2016, p. 781). Most of those interviewed talked about transnational mobility as a central part of their future trajectories. Five whose refugee protection visa applications were declined were seeking other ways of staying legally in Australia, such as marrying Australians, being enrolled in a university or college, or waiting for their children who were born in Australia to reach their tenth birthdays. Once ten, their children gain Australian citizenship ${ }^{4}$, and there is a possibility that parents can obtain permanent residency through their children.

A cosmopolitan outlook and orientation was evident among those interviewed. Interviewees actively explored opportunities to move on to another country by using their

\footnotetext{
${ }^{4}$ According to the Australian Citizenship Act 2007, a person born in Australian must be 'ordinarily resident' in Australia for ten years following their birth to be an Australian citizen (Office of Parliamentary Counsel 2016).
} 
skills, such as welding, and by collecting relevant information about schemes such as working holiday visas and refugee protection programs. They also made recourse to their North Korean diasporic networks (brokers, friends and acquaintances who have attempted onward migration). This ability to exercise agency challenges a prevalent view of North Koreans that sees them as 'fundamentally deprived of the human nature of self-autonomy and self-promotion presumed in liberal capitalism’ (Sung 2010, p. 127).

Living in Australia seems to provide North Korean refugees with new sensibilities, or ways of understanding situations through a different lens. Through a global lens, they seemed to see South Korea and South Korean policy in a more objective/positive way. They came to realise that their idealisations of Australia as a better country for refugees were not true. All of the participants clearly stated that the settlement programs the South Korean government provided were better and more generous than the ones in Australia. In particular, housing and cheap and efficient Medicare services were the most praised programs in South Korea by the interviewees.

Encounters and experiences with the ethnic 'Other' in Australia gave most North Koreans interviewed the opportunities to learn cosmopolitan values (egalitarianism and multiculturalism) to experience open-mindedness towards different cultures. They found Australia's multicultural ambience and egalitarian culture appealing, as a female interviewee in her thirties mentioned:

I have experienced no discrimination here. When I introduce myself as North Korean, people become very curious about me and try to help me and often translate what I say to other people. Because Australia is a multicultural society, people all look different and come from different cultural backgrounds. I am seen as one of them, not North Korean, and Australians cannot distinguish between South Korean and North Korean.

The identities of those interviewed seem to be no longer anchored to one location, either South Korea or North Korea. Specifically, North Korean refugees developed de-territorialised identities, such as 'Asian', and formed multiple belongings. They are able to adopt transnational practices while located in a transnational space (Fauser et al. 2012) and retain transnational ties with families and friends in South Korea, China and even North Korea by sending remittances, phone calls and instant messaging. Information and communication technologies (ICTs) play a critical role in enabling this cosmopolitanism and transnationality by facilitating transnational networking and a sense of belonging beyond geographical boundaries (Nedelcu 2012). Their onward moves have also led to the creation of new forms of transnational families out of the international movement of North Korean refugees. One couple interviewed had left two adult children in South Korea and supported them financially. One male participant sent money to his wife and two children living in South Korea. They maintained close relationships with their family members and talked to each other almost daily via Katalk (an instant messaging system), emails and international phone calls. 


\section{Conclusion: onward migration, a self-realisation strategy to be cosmopolitan}

Mobility is significant in the lives of migrants and offers an important avenue through which they can access agency as they search for a place that satisfies their social, economic and cultural needs (Skeggs 2004; Kelly 2013). However, while mobility itself is a valuable resource, it is unfortunately not one that is evenly distributed or accessed. Often only available to a privileged few, migrants wish to capitalise on the benefits of onward migration, but lack the economic, social and cultural capital (including the diasporic consciousness, diasporic networks and levels of education and skill) to successfully do so. For North Korean refugees in South Korea, in particular, who typically have never enjoyed freedom of movement, either nationally or internationally, onward migration presents as perhaps the only means through which to pursue cosmopolitan habitus. In this way, onward movement, and potentially even multiple refugee claims, constitute an opportunity to secure newfound freedom and live a cosmopolitan life.

Onward migration for North Koreans was also regarded as the means of escaping their visibility as North Korean and ridding themselves of their habitus. For most North Koreans, moving to another developed country seems to be their only opportunity to break free from their old North Korean identity. No longer perceived as North Korean, they are able to reconstruct their identity as Korean, or even cosmopolitan beyond the territorial boundary of South Korea, avoid stigmatisation and marginalisation and participate in cosmopolitan education, including English learning. In providing cosmopolitan habitus, the chance to learn English, live abroad and experience other cultures, ultimately offers an opportunity for upward social mobility for them and their children. Although at times their onward migration attempt fails, the temporary experience of living overseas itself serves as a valuable chance to taste cosmopolitan life and attain cosmopolitan habitus. Foreign language skills also see them better positioned in the global labour market in South Korea and elsewhere.

The small number of participants makes this study a preliminary one. However, the paper is the first empirical research on North Korean refugees resettled in Australia to adopt habitus as a theoretical framework, and thus provides new insight into migration studies, which focus predominately on the economic and material motives driving onward migration. Drawing from the unique experience of onward movement among North Korean refugees, the paper suggests that discarding a North Korean identity and habitus and gaining cosmopolitan habitus, and a new flexible identity, are the main reasons behind North Korean defectors' onward migration. Cosmopolitan aspiration, such as the zeal for English education in South Korea, has also pushed North Koreans to move on to Australia. This implies that reasons behind onward migration can vary according to the political and socio-cultural context of the first settled country and the origin of refugees. Furthermore, the paper argues that onward migration is not necessarily an indicator of unsuccessful integration or inadequate settlement programs in a first asylum country, but rather indicates that refugees have nurtured the ability to act on their own behalf and facilitate their own integration by continued and multiple movements. 
Distress for North Koreans does not necessarily end after fleeing their country of origin. Mobility has been crucial in reshaping the lives of North Korean refugees, some of whom have recently resettled in the UK, Canada, the US, Australia, and EU countries. Although their lives in their newly adopted countries are far from what they dreamed about when they left South Korea and other first asylum countries, North Korean refugees construct cosmopolitan lives by living across more than one country, adopting fluid identities beyond a national boundary, and retaining transnational families and networks. Yet, some North Korean refugees have been left living in limbo as a result of inconsistencies in refugee review criteria and countries' interpretations of these. Internationally consistent policies need to be developed urgently to deal with this matter, and humanitarian solutions found for North Korean refugees, who have survived extraordinary circumstances, such that their 'arduous' journey might finally end.

\section{References}

Ahrens, J., Kelly, M. \& Van Liempt, I. 2016, 'Free movement? The onward migration of EU citizens born in Somalia, Iran, and Nigeria', Population, Space and Place, vol. 22, no. 1, pp. 84-98. https://doi.org/10.1002/psp.1869.

Australian Government 2016, Australian Citizenship Act 2007, Compilation No. 24, July 1, Accessed 20 March 2017, http://www.legislation.gov.au/Details/C2016C00726

Bang Nielsen, K. 2004, 'Next Stop Britain: The Influence of Transnational Networks on the Secondary Movement of Danish Somalis’. Sussex Migration Working Paper no.22, Sussex Centre for Migration Research, Accessed 30 October 2017, https://www.sussex.ac.uk/webteam/gateway/file.php?name=mwp22.pdf\&site=252.

Beck, U. \& Sznaider, N. 2006, 'Unpacking cosmopolitanism for the social sciences: a research agenda,' The British Journal of Sociology, vol. 57, no. 1, pp. 1-23. https://doi.org/10.1111/j.1468-4446.2006.00091.x.

Bell, M. 2013, 'Why North Koreans should be allowed asylum beyond South Korea', NK News, 25 March, Accessed 25 September 2016, http://www.nknews.org/2013/03/whynorth-koreans-should-be-allowed-asylum-outside-of-south-korea/ .

Bell, M. 2014, 'Ties that bind us: transnational networks of North Koreans on the move', Resilience: International Policies, Practices and Discourses, vol. 2, no. 2, pp. 100-113. https://doi.org/10.1080/21693293.2014.914770.

Bourdieu, P. 1984, Distinction. A Social Critique of the Judgement of Taste, Routledge, London.

Bourdieu, P. 1986, 'The forms of capital' in Richardson, J.G. (ed). Handbook of Theory and Research for the Sociology of Education, Greenwood, New York, pp. 241-258.

Bourdieu, P. 1990, The Logic of Practice, Polity, Cambridge.

Charny, J.R. 2004, 'North Koreans in China: a human rights analysis', International Journal of Korean Unification Studies, vol. 13, no. 2, pp. 75-97.

Choi, L. 2011, 'British dilemmas on North Korean Refugees', October 26, [blog post]. Accessed 22 September 2016, http://blogs.lse.ac.uk/ideas/2011/10/the-british-dilemmaof-north-korean-refugees/. 
Choo, H.Y. 2006, 'Gendered modernity and ethnicized citizenship: North Korean settlers in contemporary South Korea’, Gender \& Society, vol. 20, no. 5, pp. 576-604. https://doi.org/10.1177/0891243206291412.

Chosunilbo. 2010, 'Language barrier stumps N.Korean students in South', 5 October, Accessed 22 March 2017, http://english.chosun.com/site/data/html_dir/2010/10/05/2010100501003.html .

Cohen, R. 2012, 'North Koreans in China in need of international protection', Forced Migration Review, vol. 41, pp. 42-43, Accessed 12 May 2016, www.fmreview.org/preventing/cohen.html .

Fauser, M., Voigtländer, S., Tuncer, H., Liebau, E., Faist, T., \& Razum, O. 2012, Transnationality and Social Inequalities of Migrants in Germany. SFB 882 Working Paper Series, No.11. Bielefeld: DFG Research Center (SFB) 882 From Heterogeneities to Inequalities. Accessed 22 March 2017, http://sfb882.uni-

bielefeld.de/sites/default/files/SFB_882_WP_0011_Fauser_Voigtlaender_Tuncer_Lieb au_Faist_Razum.pdf .

Federal Court of Australia 2000, Zhou v Minister for Immigration \& Multicultural Affairs [2000] FCA 811 (16 June 2000), Accessed 20 March 2017. http://www.austlii.edu.au/au/cases/cth/FCA/2000/811.html

Giddens, A. 1991, Modernity and Self-Identity: Self and Society in the Late Modern Age, Polity, Cambridge.

Hayden, M.C., Rancic, B.A. \& Thompson, J.J. 2000, 'Being international: student and teacher perceptions from international schools', Oxford Review of Education, vol. 26, pp. 107-123. https://doi.org/10.1080/030549800103890.

ICEF Monitor. 2014, 'High performance, high pressure in South Korea's education system', ICEF Monitor, 23 January, Accessed 15 May 2016, http://monitor.icef.com/2014/01/high-performance-high-pressure-in-south-koreaseducation-system/.

KEDI (Korean Educational Development Institute), 2011 A longitudinal study of North Korean migrant youth in South Korea (II), KEDI, Seoul.

Kelly, M. 2011, 'Transnational diasporic identities: unity and diversity in Iranian-focused organizations in Sweden', Comparative Studies in Africa Asia and the Middle East, vol. 31, no. 2, pp. 443-454. https://doi.org/10.1215/1089201x-1264343.

Kelly, M. 2013, Onward Migration: The Transnational Trajectories of Iranians leaving Sweden, PhD thesis, Uppsala University.

Kenway, J. \& Fahey, J. 2014, 'Staying ahead of the game: the globalising practices of elite schools’, Globalisation, Societies and Education, vol. 12, pp. 177-195. https://doi.org/10.1080/14767724.2014.890885.

Kim, J. 2013, 'Why North Koreans should be allowed asylum beyond South Korea - A response', NK News, 4 April, Accessed 20 May 2016, http://www.nknews.org/2013/04/why-north-koreans-should-be-allowed-asylumbeyond-south-korea-a-response .

Kim, M. \& Lee, D. 2013, 'Adaptation of North Korean adolescent refugees to South Korean society: a review of literature', Journal of Rehabilitation Psychology, vol. 20, no. 1, pp. 39-64. 
Korea Hana Foundation 2014, Bukhan Italjumin Siltaejosa [A survey of North Korean defectors], Korea Hana Foundation, Seoul.

Lankov, A. 2006, 'Bitter taste of paradise: North Korean refugees in South Korea', Journal of East Asian Studies, vol. 6, no. 1, pp. 105-137. https://doi.org/10.1017/s1598240800000059.

Lechte, J. 2003, Key Contemporary Concepts: From Abjection to Zeno’s Paradox, Sage, London.

Lee, B.J. 2014, Korean Jogiyuhaksaeng's early study abroad and bilingual development in Australia, PhD thesis, University of Technology, Sydney.

Lee, Y.J. \& Koo, H. 2006, “"Wild geese fathers” and a globalised family strategy for education in Korea', International Development Planning Review, vol. 28, no. 4, pp. 533-553. https://doi.org/10.3828/idpr.28.4.6.

Maxwell, C. \& Aggleton, P. 2016, 'Creating cosmopolitan subjects: the role of families and private schools in England’, Sociology, vol. 50, no. 4, pp. 780-795. https://doi.org/10.1177/0038038515582159.

Ministry of Unification. 2015, Settlement services in the initial period of settlement, Accessed 15 May 2015, http://eng.unikorea.go.kr/content.do?cmsid=3038.

National Human Rights Commission (NHRC), 2014, Survey on South Koreans' Perception about North Korean Refugees and Discrimination', NHRC, Seoul.

Nedelcu, M. 2012, 'Migrants' new transnational habitus: rethinking migration through a cosmopolitan lens in the digital age', Journal of Ethnic and Migration Studies, vol. 38, no. 9, pp. 1339-1356. https://doi.org/10.1080/1369183x.2012.698203.

Oh, W. 2011, Identity politics of young North Korean defectors: crossing the borders to and from South Korea, PhD thesis, Korea University.

Piotrowski, D. 2013, Federal court appeal for two North Koreans facing deportation, 7 May, Accessed 20 March 2017, http://www.news.com.au/national-news/federal-court-hearsappeal-for-two-north-koreans-facing-deportation/story-fncynjr2-1226636959107 .

Reay, D, Crozier, G. \& Clayton, J. 2009, 'Strangers in paradise: working class students in elite universities’, Sociology, vol. 43, no. 6, pp. 1103-1121. https://doi.org/10.1177/0038038509345700.

Refugee Review Tribunal of Australia 1996, N94/06109 [1996] RRTA 3118 (31 October 1996) Accessed 20 March 2017, http://www.austlii.edu.au/au/cases/cth/RRTA/1996/3118.html

Refugee Review Tribunal of Australia 2000, N00/31605 [2000] RRTA 225 (29 February 2000) Accessed 20 March 2017, http://www.austlii.edu.au/cgibin/sinodisp/au/cases/cth/RRTA/2000/225.html

Refugee Review Tribunal of Australia 2004, N03/47934 [2004] RRTA 148 (19 February 2004) Accessed 20 March 2017, http://www.austlii.edu.au/au/cases/cth/RRTA/2004/148.html

Refugee Review Tribunal 2005, N05/50475 [2005] RRTA 387 (24 February 2005), Accessed 20 March 2017, http://www.austlii.edu.au/au/cases/cth/RRTA/2005/387.html

Refugee Review Tribunal 2007, 071283924 [2007] RRTA 98 (29 May 2007) Accessed 20 March 2017, http://www.austlii.edu.au/au/cases/cth/RRTA/2007/98.html 
Rizvi, F. 2005, International education and the production of cosmopolitan identities. Accessed 19 March 2017, http://hdl.handle.net/2142/3516

Shin, H. 2014, 'Social class, habitus, and language learning: the case of Korean early studyabroad students', Journal of Language, Identity \& Education, vol. 13, no. 2, pp. 99103. https://doi.org/10.1080/15348458.2014.901821.

Shin, N. 2008, 'The North Korean life and adaptation in USA', 4th World Congress of Korean Studies, Fukuoka, Japan, September 22-24.

Skeggs, B. 2004, Class, Self, Culture. Routledge, London.

Stewart, J. 2012, 'North Korean family fear deportation from Australia,' ABC, 31 October. http://www.abc.net.au/news/2012-10-31/an-north-korean-family-in-australia-fearsdeportation $/ 4343578$

Sung, J. \& Go, M.-H., 2014, 'Resettling in South Korea: challenges for young North Korean refugees', Asan Institute for Policy Studies Issue Briefs, 8 August, Accessed 15 May 2016, http://en.asaninst.org/contents/resettling-in-south-korea-challenges-for-youngnorth-korean-refugees .

Sung, M. 2010, 'The psychiatric power of neo-liberal citizenship: the North Korean human rights crisis, North Korean settlers, and incompetent citizens', Citizenship Studies, vol. 14, no. 2, pp. 127-144. https://doi.org/10.1080/13621021003594783.

Takenaka, A. 2007, 'Secondary Migration: Who Re-migrates and why these Migrants Matter’, Migration Information Source, 26 April, Accessed 30 October 2017, http://www.migrationinformation.org/Feature/display.cfm?ID=597

The Guardian. 2015, 'Ask a North Korean: do you learn foreign languages?’, 5 February, Accessed 22 March 2017, https://www.theguardian.com/world/2015/feb/05/northkorea-learn-foreign-languages.

UNHCR (United Nations High Commissioner for Refugees). 2016a, UNHCR population statistics: persons of concern, Accessed 18 September 2016, http://popstats.unhcr.org/en/persons_of_concern.

UNHCR 2016b, UNHCR population statistics: asylum seekers (refugee status determination), Accessed 18 September 2016, http://popstats.unhcr.org/en/asylum_seekers.

Van Liempt, I. 2011, ““And then one day they all moved to Leicester”: the relocation of Somalis from the Netherlands to the UK explained', Population, Space and Place, vol. 17, no. 3, pp. 254-266. https://doi.org/10.1002/psp.605.

Waters J. 2008, Education, Migration and Cultural Capital in the Chinese Diaspora: Transnational Students between Hong Kong and Canada, Cambria Press, New York.

Weenink, D. 2008, 'Cosmopolitanism as a form of capital: parents preparing their children for a globalizing world', Sociology, vol. 42, no. 6, pp. 1089-1106.

https://doi.org/10.1177/0038038508096935. 